\title{
MINERAL RESOURCE POTENTIAL OF THE IRISH WILDERNESS ROADLESS AREA, OREGON COUNTY, MISSOURI
}

\author{
By \\ Allen V. Heyl, Sarah K. Odland, and C. K. Moss, U.S. Geological Survey \\ and \\ George S. Ryan, U.S. Bureau of Mines
}

\section{STUDIES RELATED TO WILDERNESS}

Under the provisions of the Wilderness Act (Public Law 88-577, September 3, 1964) and the Joint Conference Report on Senate Bill 4, 88th Congress, the U.S. Geological Survey and the U.S. Bureau of Mines have been conducting mineral surveys of wilderness and primitive areas. Areas officially designated as "wilderness," "wild," or "canoe" when the act was passed were incorporated into the National Wilderness Preservation System, and some of them are presently being studied. The act provided that areas under consideration for wilderness designation should be studied for suitability for incorporation into the Wilderness System. The mineral surveys constitute one aspect of the suitability studies. The act directs that the results of such surveys are to be made available to the public and be submitted to the President and the Congress. This report discusses the results of a mineral survey of the Irish Wilderness Roadless Area (Whites Creek) in the Mark Twain National Forest, Oregon County, Mo. The area was proposed as a wilderness under H.R. 10469, September 24, 1973, and was later classified as a further planning area (09221) during the Roadless Area Review and Evaluation (RARE II) by the U.S. Forest Service, January 1979.

\section{MINERAL RESOURCE POTENTIAL. SUMMARY}

The U.S. Geological Survey and the U.S. Bureau of Mines made a mineral and geological survey of the Irish Wilderness Roadless Area (hereafter called "study area"), southeast Missouri, in 1975-81. The study area covers 17,322 acres (7,010 hectares) in the Mark Twain National Forest in northeastern Oregon County (fig. 1).

The study area is in the southern part of the Salem Plateau region of the Ozark uplift, and contains timbered uplands bounded by the valley of the Eleven Point River on the west side. Within the study area are several narrow tributary valleys that drain southwestward into the Eleven Point River. Exposed rocks in the study area are nearly flat-lying dolomites and sandstones of Ordovician age having a total structural drop of about $10 \mathrm{ft}$ $(3 \mathrm{~m})$ from the northwest to southeast. These Ordovician strata are underlain by about $2,000 \mathrm{ft}(610 \mathrm{~m})$ of mostly dolomitic carbonate sedimentary rocks of Late Cambrian age and some beds of older Lamotte Sandstone that lie on a distinctly irregular surface of Precambrian basement igneous rocks.

There is no known record of mineral production, development, or prospecting within the study area, although some exploration holes have been drilled just east and north of the area. One prospect for iron ore is in the NW1/4 sec. 28 , T. 24 N., R. 2 W., within a private property reentrant into the area.

Several Paleozoic rock units that underlie the study area are known to be host rocks for the very important lead-zinc-copper-silver-cobalt deposits of the Viburnum Trend, north of the study area. Precambrian rocks underlying the Paleozoic units could host magnetite deposits as in the Southeast Missouri district to the north and northeast of the study area. Extrapolation of available data, especially from general knowledge of drill holes north of the study area to within a few miles of it, suggests that a high potential for similar mineral resources exists in the Irish Wilderness Roadless Area. The geophysical study of the study area (Moss, in press) indicates that several deeply buried Precambrian hills extend into and underlie the study area. These buried hills could have provided favorable traps for ore forming fluids in the Cambrian rocks that are against and cap these $k$. ls. A second favorable deeply buried structural feature is a northeast-trending, wide fault zone which crosses the northwest part of the study area. Structural disturbances have taken place in post-Precambrian time along this fault zone as shown by shearing and an abrupt southwest bend of the Eleven Point River. The potential for deeply buried metallic mineral deposits cannot be confirmed or ruled out without information obtained from drilling deep test holes within and near the study area, especially near or above the buried hills and the fault zone. Other mineral and energy resources either have a low potential in the study area or are more readily available elsewhere. 


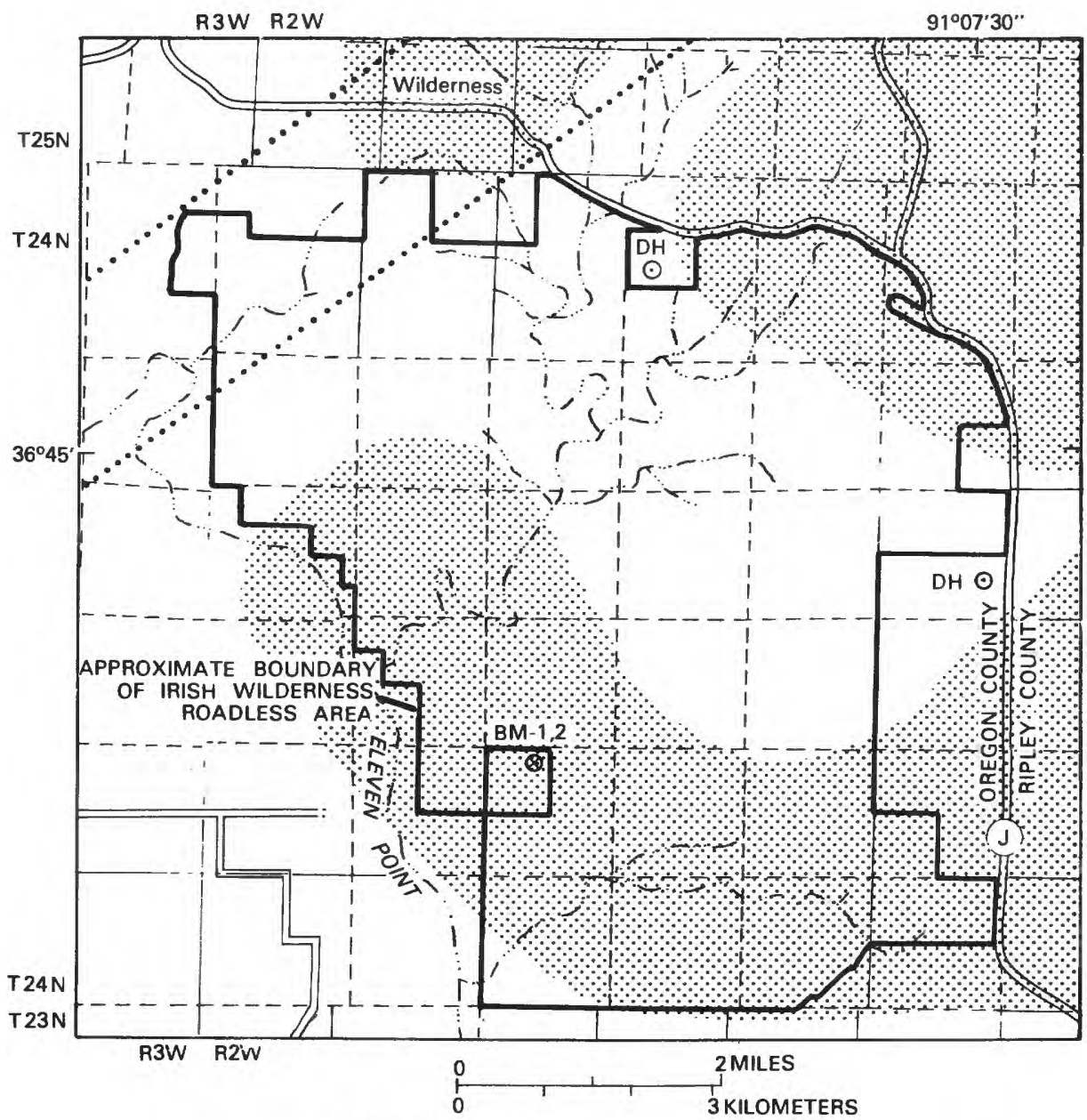

EXPLANATION

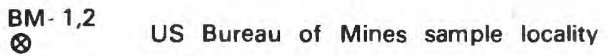

$\odot^{\mathrm{DH}} \quad$ Drill Hole

(J) County highway J

....... Outer margins of buried Precambrian fault

zone, and of shattering and shearing in

Paleozoic rocks at the surface

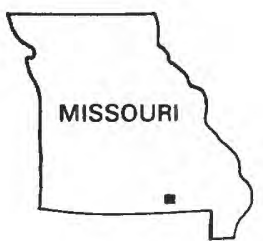

Figure 1.--Index Map of the Irish Wilderness

Roadless Area (09221) showing location of buried hills (stippled pattern) that have potential for Viburnum-type lead deposits 


\section{INTRODUCTION}

The Irish Wilderness Roadless Area in southeast Missouri covers 17,322 acres $(7,010$ hectares) in the Mark Twain National Forest in northeastern Oregon County just south of the village of Wilderness (fig. 1). The study area is most accessible by County Highway $\mathrm{J}$ which partly follows the Oregon and Ripley County line along the east side of the study area. U.S. Highway 160 is about $3 \mathrm{mi}(5 \mathrm{~km})$ south of the study area. Good township and county roads form the northeast and southern boundaries of the study area, and Forest Service trails, many traversable by pickup or jeep, provide excellent access to the study area.

The study area is within the Salem Plateau region of the Ozark uplift. The heavily timbered, nearly flat uplands are dissected by narrow entrenched tributaries of the Eleven Point River, forming steep bluff- and cliff-sided valleys. Numerous small sinkholes and a few caves, typical of karst topography, exist in and near the study area. Maximum altitude is $908 \mathrm{ft}(277 \mathrm{~m})$ in the central northern part of the study area and along County Highway $J$ in the northeast corner. The maximum topographic relief is about 450 ft $(140 \mathrm{~m})$.

\section{PREVIOUS STUDIES}

There is little published information on the study area. James G. Williams (unpub. data, 1975) of the Missouri Division of Geology and Land Survey made a survey of the exposed rock formations as viewed from a boat along the Eleven Point River and located the main units and their contacts. His work was incorporated as part of "The Geologic Map of Missouri" (Anderson, 1979). This work greatly helped in mapping the geology of the area. Heller (1954) studied the stratigraphy and paleontology of the Roubidoux Formation in the general region. Crane's (1912) report on iron deposits of Missouri describes the iron-ore prospect within the private southern reentrant where U.S. Bureau of Mines samples BM 1-2 were taken (see fig. 1).

\section{PRESENT INVESTIGATIONS}

Fieldwork by the U.S. Bureau of Mines was carried out by George S. Ryan, in 1980 and 1981. Land status records were checked at the U.S. Forest Service district office for the ownership of mineral rights in the study area. The study area was thoroughly traversed and the metallic potential of the exposed formations evaluated. An intensive search was made for prospects or- evidence of mineral deposits. None were found, and therefore only one rock sample was taken in a shallow leaf-filled pit that possibly was a prospect but could have been a sinkhole. A second sample was taken of the soil near the pit. Many mining company geologists and engineers were consulted to determine if previous work or surveys had been conducted in the study area, and none were reported by them.

Fieldwork by the U.S. Geological Survey was done in late fall of 1979 by A. V. Heyl, S. K. Odland, E. L. Mosier, J. G. Viets, and R. L. Erickson (Heyl and others, in press). The geology was mapped by Heyl, and all of the party collected stream-sediment samples. The sample preparation was done by Odland and analyses by Mosier and Viets. A geophysical survey was done by the U. S. Geological Survey (Moss, in press).

\section{ACKNOWLEDGMENTS}

We wish to thank L. D. Fellows, J. A. Martin, H. M. Wharton, and I. R. Satterfield, all of the Missouri Division of Geology and Land Survey, for their help with the stratigraphy of the area, for providing notes, and for their general assistance in many ways. We also wish to thank Stan Freeze, Leon Cambre, William Alden, James Crates, Gary Cole, and Dean Pennington of the U.S. Forest Service, Mark Twain National Forest, for several useful and constructive conferences and for their cooperation in the study.

\section{GEOLOGIC SETTING}

The study area is located on the southern upper flank of the Ozark uplift. The three rock units exposed are dolomites and sandstones of Ordovician age which throughout the area appear to be flat lying, but actually have a very gentle southerly dip from northwest to southeast. These rocks are underlain by essentially flat lying sedimentary rocks of Ordovician and Cambrian ages and by igneous basement rocks of Precambrian age having an upper very uneven erosional surface. Although Precambrian and Cambrian rocks do not crop out in the study area, they are exposed in the Eminence Hills about $30 \mathrm{mi}(50 \mathrm{~km})$ to the north, and they have been identified in drill holes near the north and east sides of the area. In descending order, the exposed geologic units in the study area are as follows: Quaternary alluvium as valley fill, residuum derived from weathering of Jefferson City Dolomite, Ordovician Jefferson City Dolomite, Ordovician Roubidoux Formation (both sandstone and dolomite), and the upper part of the Ordovician Gasconade Dolomite. The subsurface units are the remaining minimum of $200 \mathrm{ft}(60 \mathrm{~m})$ of Gasconade Dolomite, about $300 \mathrm{ft}(90 \mathrm{~m})$ of Cambrian Eminence Dolomite containing some sandstone, $350 \mathrm{ft}$ $(110 \mathrm{~m})$ of Cambrian Potosi Dolomite, $300 \mathrm{ft}(90 \mathrm{~m})$ of Cambrian Derby-Doerun Dolomite (of Anderson, 1979), $30 \mathrm{ft}(9 \mathrm{~m})$ of Cambrian Davis Formation (mostly dolomitic shale), $450 \mathrm{ft}(140 \mathrm{~m})$ of Cambrian Bonneterre Formation, 0-500 ft (0-150 m) of Lamotte Sandstone, and Precambrian gneiss and granite, thickness unknown.

\section{STRUCTURE}

The surface geologic structure in the study area is fairly simple. The strata have a very gentle southerly regional dip in this part of the Ozark 1 lift, having a structural relief of about $10 \mathrm{ft}(3 \mathrm{~m})$ from the northwest part to the southeast part of the study area. The only other surface feature, besides small sinkholes and caves, is the surface expression of a 1.4mi- $(2.2-\mathrm{km}-)$ wide northeast-trending fault zone in the Precambrian basement (fig. 1). Surface strata contain evidence (brecciation) of only slight shearing. 
Brecciation of surface strata more or less parallels the fault zone in the Precambrian subsurface at a depth of about $1,600 \mathrm{ft}(490 \mathrm{~m})$. In addition, a sharp southwest bend in the Eleven Point River is present a short distance southwest of the northwestern edge of the study area (fig. 1), which suggests that this bend follows the sheared zone.

Deeply buried Precambrian hills of felsic igneous composition underlie the study area as shown by geophysical studies of Moss (in press). The largest area of buried hills that underlies the study area extends from its southeast corner and to the west and northwest and almost to the southeast edge of the fault zone noted previously. East of the study area it is connected to a second very large hill area on the Precambrian paleosurface that is centered northeast of the study area's northeast corner and extends into the northeast part of the study area about $0.5-1 \mathrm{mi}$ $(0.8-1.6 \mathrm{~km})$. A third area of hills extends southward into the northeast-trending fault zone.

The buried fault zone is well located by the electromagnetic geophysical studies (Moss, in press) and it is potentially favorable for solution flow and may have been favorable for the development of algal finger reefs within it and along its southeast margin because of prevailing northwest wind direction during Ordovician time. The presence of such reefs, however, must be demonstrated by deep drilling. Moss points out that the concealed fault shows a strong rightlateral strike-slip component of movement, and he interprets the electromagnetic anomaly as caused by a Precambrian dike which in part intruded and dilated the fault zone.

\section{GEOCHEMISTRY}

Spectrographic analyses of 35 samples (Heyl and others, in press) of minus-80-mesh stream sediments and their corresponding panned concentrates, from streams within or draining the study area, indicate very local and minor anomalously high metal content in the surface formations of the study area. All samples were analyzed for 28 elements: $\mathrm{Pb}, \mathrm{Zn}, \mathrm{Cu}$, $\mathrm{Co}, \mathrm{Ni}, \mathrm{Mo}, \mathrm{Ag}, \mathrm{As}, \mathrm{Fe}, \mathrm{Mg}, \mathrm{Ca}, \mathrm{Ti}, \mathrm{Mn}, \mathrm{B}, \mathrm{Ba}, \mathrm{Be}, \mathrm{Cd}$, $\mathrm{Ce}, \mathrm{Cr}, \mathrm{La}, \mathrm{Nb}, \mathrm{Sb}, \mathrm{Sc}, \mathrm{Sr}, \mathrm{V}, \mathrm{W}, \mathrm{Y}$, and $\mathrm{Zr}$. The stream sediments consist chiefly of quartz grains, quartz druse, chert, and iron oxides, and the panned concentrates consist almost entirely of iron oxides derived from both the exposed strata and residuum of younger formations. The geochemical studies of stream sediments in southeast Missouri indicate that the trace element suites of metals related to mineralization are contained in iron sulfides and iron oxides derived from iron sulfides (Erickson and others, $1978,1979)$. Analyses of the possibly metal rich iron oxides, therefore provide a guide to potentially favorable ground for mineral resources. Except for molybdenum and lead, the concentrations of other metals in the Irish Wilderness Roadless Area are comparable to those obtained in other southeast Missouri wilderness areas by Erickson (Pratt and Erickson, 1982; Pratt, Mosier, and Ellis, 1982). In those nearby wilderness areas lead contents are an order of magnitude higher than in the Irish Wilderness Roadless Area and molybdenum is not detected. Except for a few high values, the concentration of metals within the stream concentrate samples in and marginal to the study area show a high degree of homogeneity. A few sites have anomalous values of zinc, nickel, cobalt, and copper, but a meaningful pattern of metal distributions and abundances at the surface, which would indicate favorable ground for deep metal discovery, could not be recognized.

Because the iron oxides and their associated trace metals are derived from the Ordovician Gasconade Dolomite and younger formations, these 35 samples of stream sediments cannot effectively evaluate the mineral potential of the underlying Cambrian Bonneterre Formation, which is considered to be the most favorable host for lead deposits in southeast Missouri.

Recently released geochemical data from a drill hole several miles north of the study area suggest that if significant mineral deposits are present beneath the study area, they could be in the upper Bonneterre, but are more likely to be in the Derby-Doerun or Potosi Dolomites, which stratigraphically overlie the Bonneterre Formation. Further drill-hole data are needed to determine the distribution, abundance, and significance of the analytical results from the released drill-hole data with respect to lead, silver, copper, and other associated metals in the underlying formations of the study area.

\section{GEOPHYSTCS}

Because the Viburnum-Trend types of ore deposits are among the most important to the nation and southeast Missouri (Economic Geology, 1977, p. 337-490), the primary emphasis of the geophysical investigation by Moss (in press) was an assessment of the possibilities for and detection of deeply buried, large base metal deposits containing lead, zinc, silver, copper, and cobalt in the Bonneterre Formation. A secondary emphasis was to determine the potential for iron and copper deposits associated with Precambrian lithology and structure as delineated by geophysical data.

An aeromagnetic survey of the study area was made by the U.S. Geological Survey in early 1980 (Moss, in press); the acquired information provided the foundation for all of the geophysical interpretations presented here. For reference purposes, an independent interpretation of the survey data was obtained under contract from a commercial organization. This interpretation (A. Spector, unpub. data, 1980) has been used to augment the work of Moss.

Depth soundings using electromagnetic and resistivity techniques were made at several sites within and adjacent to the study area (Moss, in press). The objective of the electromagnetic and resistivity work was to obtain data that would supplement that provided by the aeromagnetic survey, so that an assessment of potential for Viburnum-type deposits could be made. However, adverse geologic conditions resulted in interpretations of only marginal accuracy for the purpose needed. A short discussion of the work is included in the next section, but a detailed evaluation of the results is not provided.

Preliminary estimates placed the Bonneterre host rocks at a depth between 1,500 and $2,000 \mathrm{ft}(460$ and $610 \mathrm{~m}$ ). Because of the nearly 2,000-ft depth, the use of geophysical methods was not believed feasible 
for direct detection of Viburnum-type deposits which might be present. Consequently, geophysical procedures followed an indirect approach designed to determine whether favorable, unfavorable, or preclusive geologic conditions for these deposits exist in the study area.

The Viburnum-type deposits are found in the lowest carbonate formation (Bonneterre Formation) of a thick section of Cambrian sediments that rests unconformably on an irregular Precambrian basement surface. The strata have been subjected to episodes of uplift and subsidence, but have undergone only minor tilting in the study area.

Favorability for a Viburnum-type deposit is highest for an area in which basement hills rise above the Lamotte pinchout, and thus provided a base for deposition of nearshore facies of the Bonneterre Formation.

A measured altitude of the Precambrian basement surface is known from a drill hole approximately $2.5 \mathrm{mi}(4 \mathrm{~km})$ north of the study area (Moss, in press). The drill-hole data indicate that the Lamotte Sandstone, as well as the Bonneterre Formation, may be expected in the study area wherever the basement elevation is lower than approximately $1,400 \mathrm{ft}(430 \mathrm{~m})$ below sea level.

Figure 1 shows the areas of Precambrian buried hills and the fault interpreted from an aeromagnetic contour map (Moss, in press) of the study area. An assumption is made by Moss that the magnetic expression on the map reflects primarily the lithologic and structural complexities of the Precambrian basement. This is based upon prior observations that the igneous rocks of the basement have much stronger magnetic properties than do the overlying sediments (Allingham, 1976). To a lesser degree, the magnetic map must also contain effects produced by relief in the basement surface.

The pattern of basement elevations shown by the interpretation of magnetics is significant even though data points are sparse. Four elevation points on the southwest border of the study area indicate that the underlying basement there has an elevation of approximately $1,600 \mathrm{ft}(490 \mathrm{~m})$ below sea level. This elevation might be considered "normal" for the region, and a significant thickness of both the Lamotte Sandstone and the Bonneterre Formation would be expected using the drill-hole section from Moss (in press) as a model. Eastward, a sequence of three elevation points shows a rising basement, with an indicated elevation of approximately $800 \mathrm{ft}(240 \mathrm{~m})$ below sea level at the east border. Immediately north of the northwest quarter of the study area, a set of three elevation points indicates another basement high, in this case having an average elevation of approximately $350 \mathrm{ft}(110 \mathrm{~m})$ below sea level.

In a qualitative sense, the results of the electromagnetic soundings suggest that depths to the Davis Formation and the basement become shallower going from west to east in conformance with the magnetic interpretation above. However, the electromagnetic results are ambiguous regarding the trend from south to north.

The depth interpretations in total indicate a basement relief of anomalous magnitude within the study area. Pinchouts of the Lamotte Sandstone appear likely within the study area along lines projected northward and eastward from the southwest border. This conclusion is valid even if the upper limit of the Lamotte pinchout is, in reality, substantially higher than the extrapolated value of $1,290 \mathrm{ft}(388 \mathrm{~m})$ below sea level.

In essence, the aeromagnetic interpretations support the conclusion that certain basic geologic conditions are favorable for Viburnum-type deposits to be present within the study area. Locations of these geologic features cannot be defined in specific terms.

Precambrian magnetite deposits and magnetitecopper deposits of economic importance have been found in southeast Missouri and are the kinds of deposits which might be detected by a magnetic survey. No feature on the aeromagnetic map (Moss, in press), however, is characteristic of such a source from which an intense local anomaly would be expected (Allingham, 1976).

Tentative interpretations of basement lithology can be made from the aeromagnetic map in terms of rock types which have been mapped in the St. Francois Mountains (approximately $65 \mathrm{mi}(110 \mathrm{~km})$ northnortheast), and intersected in drill holes nearer to the study area (Kisvarsanyi, 1975). The low magnetic relief in the southwest third of the aeromagnetic map suggests a basement rock of felsic composition having appreciable depth-probably a granite. Other anomalies suggest basement rocks of intermediate composition-probably in the form of a band of volcanics or a dikelike intrusion. At the same time it should be emphasized that the magnetic picture in no way implies an absence of mineral potential in the local Precambrian rocks.

A linear, northeast-trending feature as shown on the aeromagnetic map of Moss (in press) has an apparent relationship to an inferred fault showing a strong right-lateral strike-slip component. This inferred fault cuts previously existing anomalies to produce offset parts of the bordering rocks. An anomaly within the fault zone shown in the northwest part of the study area is interpreted to be caused by a Precambrian dike which has intruded and dilated the fault zone.

Direct evidence of rejuvenated faulting is not apparent in the Paleozoic surface rocks, but it is noteworthy that the anomalous course of the Eleven Point River near the northwest corner of the study area was recognized early by Heyl as being probable evidence of faulting. That interpretation is now given support by the aeromagnetic data.

\section{MINING DISTRICTS AND MINERALTZED AREAS}

The U.S. Government purchased the Irish Wilderness Roadless Area as a part of Mark Twain National Forest in the late 1930's and early 1940's. All of the mineral rights in the study area have been held by the U.S. Government since the 1950's. No prospecting permits are on record, although some have recently been requested by major companies $\supset$ drill for lead deposits.

Previous mining activity consisted of mining brown iron ore in 1907 from the Burgesser mine in sec. 28, T. 24 N., R. 2 W. Crane (1912) describes this deposit and the mine from which 23 tons (21 metric tons) of ore containing $\mathbf{5 2 . 8}$ percent iron were shipped in 1907 . The mine could not be precisely located in 1980. 
No mining districts are in or near the study area. Individual, small, mineralized areas, consisting mainly of zinc carbonates or brown iron oxides, are found throughout southern Missouri. These deposits do not appear to be related to one another or to the deeper lead-zinc deposits of the major districts (Melton, 1978).

Zinc carbonates were mined by open-pit methods $8 \mathrm{mi}(10 \mathrm{~km})$ west of the study area near Alton, Mo. Known as the C.S.R. or Burkhardt mine, this operation produced 300 tons (270 metric tons) of ore between 1910-1917 (Missouri Department of Natural Resources, unpub. data, 1963). All production was from within $125 \mathrm{ft}(38 \mathrm{~m})$ of the surface.

Brown-iron-residual-type ore deposits have been mined in southern Missouri since 1815 (Clark and Muilenburg, 1954). Most of the production was prior to 1912, but activity occurred during the depression years of the 1930's and during World War II. According to Miller (1982), only a very few brown-iron-ore mines remain active. Low-grade ore, high-cost transportation, and limited tonnages preclude development of operations in the near future, but at intervals, small tonnages of iron ore have been mined and shipped.

In "Notes on Uranium," Muilenburg (1949) mentions radioactive nodules northwest of Bardley. "The carbonaceous nodules are sparsely distributed in a lens about $18 \mathrm{in}$. thick and some $40 \mathrm{ft}$ long." This deposit was determined to be located in sec. 28, T. 24 N., R. 2 W., the same section that includes the Burgesser mine.

One of the world's most productive mineral zones is $45 \mathrm{mi}(72 \mathrm{~km})$ north of the study area. The New Lead Belt, also known as the Viburnum Trend, is a subdistrict of the Southeast Missouri Lead District. Production from the New Lead Belt accounted for 89 percent of the lead produced in the United States in 1980. In addition to being the number one producer of lead in 1979, the New Lead Belt accounted for 23 percent of the zinc, 5 percent of the silver, and 1 percent of the copper production in the United States (G. S. Ryan, U.S. Bureau of Mines, written commun., 1982). Cobalt, nickel, and cadmium are also produced as byproducts. All of the production was from the Upper Cambrian Bonneterre Formation, which is known to underlie the Irish Wilderness Roadless Area. To the north of the Viburnum Trend at the Indian Creek mines, large tonnages of lead were produced from the Lamotte Sandstone, and from two of the uppermost Cambrian formations large amounts of lead and huge amounts of barite were produced. Major iron deposits are and have been mined from the Precambrian rocks.

Many of the major exploration companies have been drilling the area between the Ozark Lead Company mine near Sweetwater, Mo. (at the south end of the Viburnum Trend) and the Irish Wilderness Roadless Area. Ore bodies within the present New Lead Belt are nearly continuous for about $40 \mathrm{mi}(60$ $\mathrm{km}$ ), are elongate, range from 500 to $2,000 \mathrm{ft}$ (150 to $610 \mathrm{~m}$ ) wide, and lie in a north-south alinement that projects toward the Irish Wilderness Roadless Area.

ASARCO and St. Joe Minerals Corporation each drilled one hole immediately adjacent to the study area boundary. ASARCO drilled in the NW1/4 sec. 6 , T. 24 N., R. 2 W., and St. Joe drilled in the SE1/4 sec.
13, T. 24 N., R. 2 W. (see fig. 1). Other than the fact that the drilling penetrated the Bonneterre Formation between 1,600 and $1,800 \mathrm{ft}(490$ and $550 \mathrm{~m})$, no information has been made public by the companies. Another ASARCO hole was drilled in the S1/2 sec. 22, T. 25 N., R. 2 W. Lithologic and geochemical studies were done and released on this hole, which was barren.

All prospecting on Federal lands in Missouri must be done on a permit basis. Prospect permits are obtained from the U.S. Bureau of Land Management with follow-up leases dependent upon proof of oregrade mineral deposits having been located. Most of the present exploration drilling in the vicinity of the study area is being conducted on leased private property. Increasingly large numbers of exploration permits for drilling within the Mark Twain National Forest are being sought; one application for a drilling permit for the N1/2 sec. 13, T. 24 N., R. 2 W., within the Irish Wilderness Roadless Area, was made in 1979 and is still pending as of May 1981. Since 1981, Cominco American has applied for drilling permits in the study area.

Numerous small pits in and near the study area are in detrital material; such pits may have been dug to determine the possible existence of surficial ironoxide or zinc-oxide deposits common to southern Missouri. No samples were taken within the study area during this examination as no unusual mineralized rock conditions were observed. Two samples (fig. 1), taken near the study area at the same sample site, were not highly mineralized.

\section{MINERAL RESOURCE POTENTIAL}

Several of the rock units that underlie the study area are known to be host rocks in nearby areas and therefore have potential for mineral deposits. The two most important categories are the Cambrian dolomites and sandstones, which contain the lead-zinc-silvercopper-cobalt deposits and the barite-lead-zinc deposits of the Southeast Missouri Lead District, and the Precambrian igneous rocks, which contain magnetic-iron ore deposits and magnetite-coppersulfide deposits.

\section{Lead-Zinc-Silver-Copper-Cobalt Deposits}

The Bonneterre Formation underlies southeast Missouri including the study area. Most production from the lead belts came from zones in the Bonneterre Formation where reef conditions, structures, and associated carbonate facies are present (Gerdemann and Myers, 1972). The pinch-outs of the formation against buried Precambrian hills are particularly favorable. Similar geologic conditions are present in the study area, as shown by geophysical studies by Moss (in press), and a high potential for significant lead-zinc mineral deposits exists based on location and orientation to the Viburnum Trend. Much drilling has been done 3-12 mi $(5-20 \mathrm{~km})$ north of and east of the study area by several companies, and it is commonly known that some mineralized rock has been found. Also, several drill holes have been drilled at the north and east margins of the area, but the information obtained from them has not been released. It is known among most of the companies prospecting in the region that Viburnum-Trend-type deposits possibly extend 
south toward the Irish Wilderness Roadless Area, and companies have applied for leases to prospect within it.

The existence of faulting within the Precambrian rocks might be a justification for considering mineral resource potential in those rocks. On the other hand, faulting or fracturing in the Bonneterre Formation could have a tangible bearing on mineral resource potential within a setting otherwise favorable for Viburnum-type deposits (Economic Geology, 1977, p. 440) such as reefs marginal to the fault zone. In net effect, the evidence of faulting carries a positive bias for mineral potential in the northwest part of the study area.

In the Fredricktown area of the Southeast Missouri Lead District, about $43 \mathrm{mi}(70 \mathrm{~km})$ northeast of the study area, large reserves containing cobalt, nickel, copper, and lead are known. Cobalt is on the United States' critical mineral list. Cobalt, copper, and nickel have been produced here since 1844 , and at least 5.2 million pounds of cobalt were produced up to 1961 (Vhay and others, 1973, p. 144). Until the 1982 recession stopped activities, Anschutz Minerals Corporation was reopening mines and producing cobalt from old surface piles. A large copper-cobalt-nickel anomaly is about $9-12 \mathrm{mi}(14-20 \mathrm{~km})$ north of the study area (Erickson and others, 1978) and has a north-south trend. Such ores could underlie, at depth, the Irish Wilderness Roadless Area.

The magnetic interpretations support the conclusion that certain basic geological conditions favorable for Viburnum-type deposits are present in the study area (Moss, in press). The studies completed to date cannot be considered definitive.

\section{Zinc-Lead-Barite Deposits}

The nearest drill hole from which data have been released, is several miles north of the study area and shows favorable facies for zinc-lead-barite deposits in the Bonneterre Dolomite. Also, anomalous concentrations of zinc and lead have been found to the northwest in the other Upper Cambrian strata overlying the Davis Formation. There is a moderate potential for zinc-lead-barite deposits in the Upper Cambrian formations which lie above the Davis Formation.

\section{Magnetic Iron Ore Deposits}

The known magnetite iron-ore deposits in the Southeast Missouri Lead District comprise several magnetite-hematite concentrations in Precambrian silicic volcanic rocks and one copper-bearing magnetite deposit in Precambrian syenite (Kisvarsanyi, 1977). The irregular, hilly surface of the Precambrian rocks in the Irish Wilderness Roadless Area is estimated to be about $1,600 \mathrm{ft}(490 \mathrm{~m})$ below the bed of the Eleven Point River. The Precambrian rocks underlying the study area are thought to be gneiss and granite (Kisvarsanyi, 1979) and a dacitic or andesitic dike or band of intermediate composition. In the subsurface, volcanic rocks fill the broad fault zone in the northwest part of the study area. Parts of the aeromagnetic anomalies in the buried hills to the northwest and southeast of this dike (in the northeast corner of the study area) may also be of intermediate composition (Moss, in press). The rest of the aeromagnetic anomalies suggest rocks of felsic composition, particularly in the southern part of the study area.

In some mineral districts (such as Iron Mountain) certain granitic igneous rocks have a specific relationship to iron mineralization, but Moss (in press) notes that the lack of a similar relationship of local small areas of magnetic high anomalies in the study area precludes the interpretation of magnetic anomalies attributable to Precambrian iron deposits. No feature on the aeromagnetic map (Moss, in press) is characteristic of such an iron deposit, from which an intense local anomaly might be expected. The magnetic pattern in no way implies an absence of mineral potential in Precambrian rocks, especially if most of the magnetite has been changed to hematite, or copper minerals are present.

\section{Iron Ores In Sedimentary Rocks}

The Irish Wilderness Roadless Area lies within the southern part of the area of residual-limonite deposits. The Burgesser residual-limonite deposit was once mined in a private land reentrant in the study area. Within the study area no large concentrations of residual limonite were seen, and the potential for large quantities is low.

\section{Construction Materials}

Both the Roubidoux Formation and the Gasconade Dolomite have been quarried for building stone and crushed rock outside of the study area. The sand in the Roubidoux Formation here is too impure for silica sand use. The Gasconade Dolomite here contains 7-10 percent chert and is not usable for refractory material. Both of these formations are abundant over very large areas of southern Missouri outside of the study area.

\section{Energy Sources}

The central part of the Ozark uplift is considered to be very unfavorable for oil and gas occurrence (Wharton and others, 1969). The few pieces of radioactive rock found in the southwestern reentrant suggests little or no potential for radioactive mineral deposits.

\section{REFERENCES CITED}

Allingham, J. W., 1976, Interpretation of aeromagnetic anomalies in southeastern Missouri: U.S. Geological Survey Open-File Report 76-868, 319 p.

Anderson, K. H., 1979, The geologic map of Missouri: Missouri Division of Geology and Land Survey, scale $1: 500,000$.

Clark, E. L., and Muilenberg, G. K., 1954, The brown iron ore resources of Missouri: American Institute of Mining, Metallurgical, and Petroleum Engineers, Transactions, p. 63-66.

Crane, G. W., 1912, The iron ores of Missouri: Missouri Bureau of Geology and Mines, v. 16, 434 p. 
Economic Geology, 1977, An issue devoted to the Viburnum Trend, southeast Missouri: Economic Geology, v. 72, no. 3, p. 337-490.

Erickson, R. L., Mosier, E. L., and Viets, J. G., 1978, Generalized geologic and summary geochemical maps of the Rolla $1^{\circ} \times 2^{\circ}$ quadrangle, Missouri: U.S. Geological Survey Miscellaneous Field Studies Map MF-1004-A, scale 1:250,000.

Erickson, R. L., Mosier, E. L., Viets, J. G., and King, S. C., 1979, Generalized geologic and geochemical maps of the Cambrian Bonneterre Formation, Rolla $1^{\circ} \times 2^{\circ}$ quadrangle, Missouri: U.S. Geological Survey Miscellaneous Field Studies Map MF-1004-B, scale 1:250,000.

Gerdemann, P. E., and Myers, H. E., 1972 , Relationships of carbonate facies patterns to ore distribution and to ore genesis in the Southeast Missouri lead district: Economic Geology, v. 67, no. 4, p. 426-433.

Heller, R. L., 1954, Stratigraphy and paleontology of the Roubidoux Formation of Missouri: Missouri Division of Geological Survey and Water Resources, v. 35, 2d ser., 118 p.

Heyl, A. Vo, Odland, S. K., Viets, J. G., Mosier, E. L.os and Erickson, R. L. (in press), Geologic and geochemical map of the Irish Wilderness Roadless Area, Oregon County, Missouri: U.S. Geological Survey Miscellaneous Field Studies Map MF-1511-C, scale 1:24,000.

Kisvarsanyi, E. B., 1975, Data on Precambrian in drillholes of Missouri including rock type and surface configuration: Missouri Geological Survey Report of Investigations 56, 20 p.

1979 , Structure contour map of buried Precambrian basement-rock surface, eastern part of the Rolla $1^{\circ}$ by $2^{\circ}$ quadrangle and adjacent areas, Missouri: U.S. Geological Survey Miscellaneous Field Studies Map MF-1001-A, scale $1: 250,000$.
Kisvarsanyi, Geza, 1977, The role of the Precambrian igneous basement in the formation of the stratabound lead-zinc-copper deposits in southeast Missouri: Economic Geology, v. 72, no. 3, p. 435-442.

Melton, D. C., 1978, Base metal mineralization in south central Missouri: Rolla, University of Missouri M.S. thesis, 140 p.

Miller, M. H., 1982, Mines, prospects, and occurrences of metallic minerals in the Rolla $1^{\circ} \times 2^{\circ}$ quadrangle, Missouri: U.S. Geological Survey Miscellaneous Field Studies Map MF-1005-B, scale $1: 250,000$.

Moss, C. K. (in press), Geophysical investigation of the Irish Wilderness Roadless Area, Oregon County, Missouri: U.S. Geological Survey Miscellaneous Field Studies Map MF-1511-B, scale 1:24,000.

Muilenberg, G. A., 1949, Notes on uranium: Missouri Geological Survey and Water Resources Information Circular 5, $22 \mathrm{p}$.

Pratt, W. P., and Erickson, R. L., 1982, Geologic, geochemical, and geophysical maps of the Bell Mountain Wilderness Study Area, Iron County, Missouri: U.S. Geological Survey Miscellaneous Field Studies Map MF-1178-A, scale 1:24,000.

Pratt, W. P., Mosier, E. Lo, and Ellis, Clarence, 1982, Geology and mineral resource potential of the Paddy Creek Wilderness Study Area, Texas County, Missouri: U.S. Geological Survey Miscellaneous Field Studies Map MF-1286, scale $1: 24,000$.

Vhay, J. S., Brobst, D. A., and Heyl, A. V., 1973, Cobalt, in Brobst, D. A., and Pratt, W. P., eds., 1973, United States mineral resources: U.S. Geological Survey Professional Paper 820, p. 143-155.

Wharton, H. M., Martin, J. A., Rueff, A. N., Robertson, C. E., Wells, J. S., and Kisvarsanyi, E. B., 1969, Missouri minerals-resources, production, and forecasts: Missouri Geological Survey and Water Resources Special Publication 1, xi + 303 p. 